\title{
15. Microspectrophotometric Screening System with Multi-Fiber Scanning, Practically Feasible for the Detection of Premalignant and Malignant Lesions of the Cervix
}

\author{
A Preliminary Note
By Iwao Nishiya,*) Yoshiaki Ishizakr,*) Keisuke ShimotomaI,*) Ichiro SAWAMURA,**) Kohichi TAMURA,***) and Masayoshi AKAMA***) \\ (Communicated by Sajiro Makino, M. J. A., Feb. 12, 1980)
}

Recently, researches in the field of automated cytology have been carried out according to two systems. One is quantitative cytology based on the automated analytic system set up for basic researches of cancer cells (Melamed et al. 1976). The other is the population screening method applicable to the study of cervical carcinoma (Herman et al. 1976) which has been utilized in our country for a couple of ten years. This method has been clinically recognized as an effective diagnostic means in early cancer, as well as noted as an efficient detection method of precancerous lesions. To increase the efficiency of processing a large number of specimens, the practical application of the automated cytology screening system becomes necessary as a matter of course. In the Japanese method, smearing is made on the slide glass and stained; then the cells are scanned, and then adjudgement is made.

In 1971 we developed a microspectrophotometry technique based on our original method with bundled glass fibers for scanning (Nishiya et al. 1977). Use being made of this technique we undertook a comparative study of 310 cases from various lesions of cervix uteri on the basis of the spot measurement as well as of the scanning measurement, and were able to present some essential criteria and standards for automated cytology.

Following this preliminary study, we have undertaken with this technique examinations of 177 cases of the cervix which were clinically diagnosed. This has made possible the recognition that this method could be practically feasible for the detection of malignant lesions.

\footnotetext{
*) Department of Obstetrics and Gynecology, School of Medicine, Hokkaido University, Sapporo.

**) Medical Technology Branch, Olympus Optical Co., Ltd., Tokyo.

***) Cytology Laboratory, Hokkaido Cancer Society, Sapporo.
} 
Materials and methods. The following examinations were done on female subjects attending to outpatient clinic of the Hokkaido University Hospital and the Detection Center for Cancer, Hokkaido Cancer Society. The ecto- and endocervical areas were scraped with an Ayre's spatula, cell suspensions were preserved at $4{ }^{\circ} \mathrm{C}$, and the cells were centrifuged onto the slide glass through mesh filter (80 micron in diameter) from a plastic container by autosmear apparatus. For hematoxylin stainning, the autostainer for Papanicolaou stainning was used. The stainning process was stopped automatically following the stage of hematoxylin stainning. When further stainning was done in the process of Papanicolaou stainning, the observations of the machine-selected cells were possibly made under a light microscope. For the measurement of the relative DNA content in individual cells, smears were processed according to the Feulgen nuclear reaction (Shibatani et al. 1972). 100-200 cells were measured with the microspectrophotometer (Olympus MMSP-C) for the nuclear DNA content and histograms were prepared for respective purposes. In order to see the correlation between the spot measurement and the scanning measurement, the measured values of glass fibers, 1, 4 and 10 micra in diameter, were investigated in detail. It was revealed that in the case of four micron fiber the most favorable correlation was demonstrated. The detection of nuclear size could be done with correlation coefficient in 0.86 .

To improve the efficiency of scanning, 16 glass fibers were arranged on the diaphragma in a rod fashion, and the absorbance (A) $\times$ length (L) was calculated in nuclear diameter of each fiber. The total amount $(\mathrm{M})=\mathrm{K} \cdot \mathrm{AL}^{2}(\mathrm{~K}$ : coefficient) per cell which was in turn integrated by a minicomputer was obtained (Fig. 1). When the samples were moved on the stage, the feature is shift out of the focus. It is corrected in the following manner: A correct position is taken on the site where the most favorable contrast image is obtained, and the best focus is adjusted by the minicomputer as mentioned above. In scanning area, the focus is accomplished while a shift from $\mathrm{A}$ to $B$ point is being made, and five areas in $1 \mathrm{~mm}^{2}$ are continuously scanned. For practical use as an automatic prescreening of uterine cancer, an apparatus for the simultaneous determination of the total amount of nuclear density and nuclear size of premalignant and malignant cells was fabricated (Fig. 4).

With the preparation technique as above described, 177 cases from the various lesions of the cervix were examined, and the final diagnoses of lesions were made following the histological examinations of the excised subjects.

Results. The histograms of the nuclear DNA content were ob- 
tained in 50 cases of normal cervix, as well as in 500 peripheral lymphocytes. The histogram from a total of 310 cases were examined. They consisted of 25 cases of reserve cell hyperplasia and metaplasia with histological diagnoses, 33 cases of mild dysplasia and 40 cases of severe dysplasia, 97 cases of carcinoma in situ, 45 cases of microinvasive carcinoma and 70 cases of frankly invasive carcinoma diagnosed from biopsy and/or step sections of excised materials.
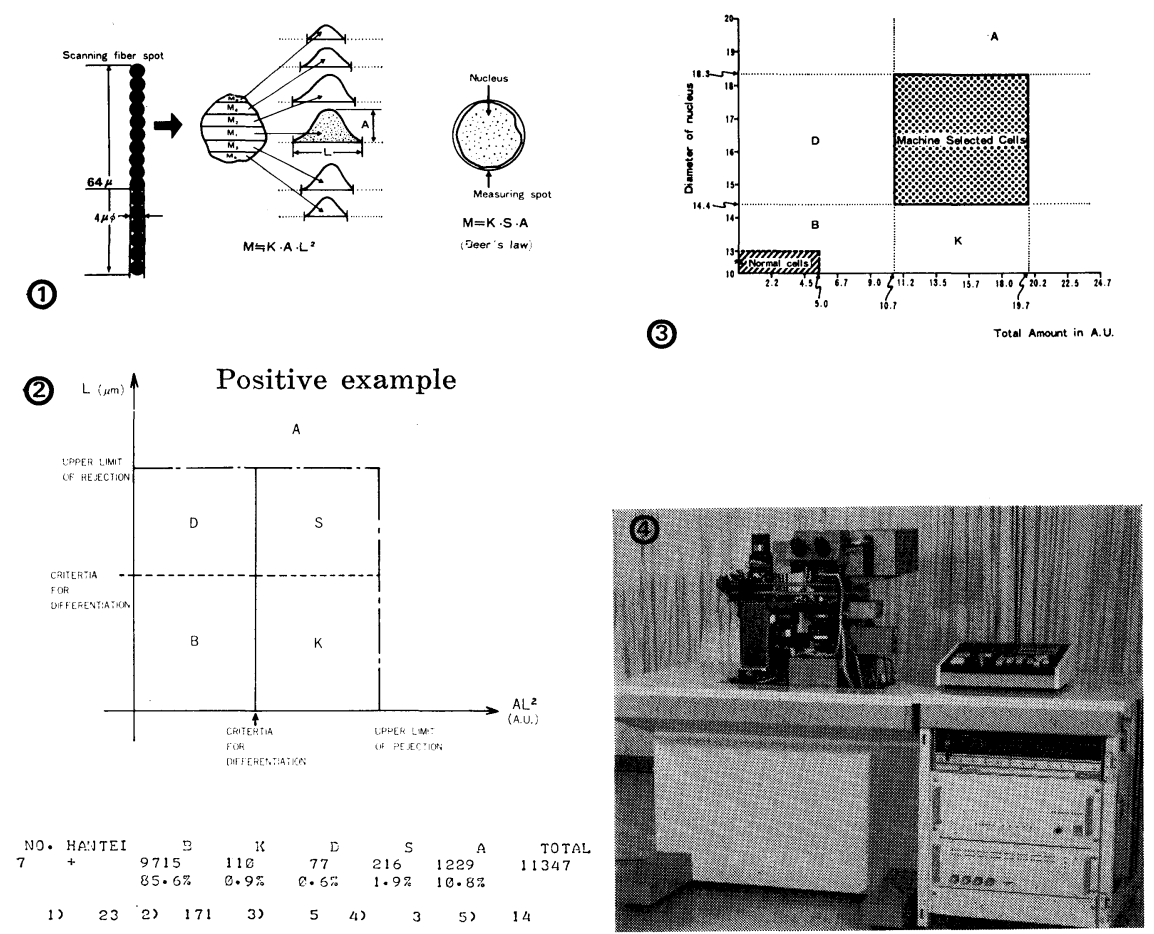

Figs. 1-4. 1: Multiphase (fibrooptic) scanning method and spot method. 2: Positive examples. 3: Criteria for automation cytology in prescreening of cervical cancer (Feulgen-reactive DNA). 4: Newly designed microspectrophotometry apparatus (Sawamura et al. 1978).

In general, an automated screening for cancer may contain a reasonable false positive rate, because the number of cases missed should be minimal. A relatively high false positive rate in the screening can be tolerated, since it substantially reduces the load of visual screening. On this view, a cut off point in nuclear DNA content and nuclear size were calculated to be $95 \%$ negative cells $(\mathrm{P}<0.05)$ in mild dysplastic lesions. Since it is difficult to completely prevent false positives caused by cell aggregations, we set an upper limit $(p<0.05)$ in the measurements of nuclear DNA content and nuclear size of a single malignant cells. Fig. 3 shows criteria for Feulgen specimens. 
We show here an example which was observed to be positives (Fig. 2). In five scanning areas, the total cell number measured was 11347, in which benign cells (B) were 9715 (85.6\%). This appears to indicate that karyopyknotic cells $(\mathrm{K})$ which are smaller in size than threshold ones are $110(0.9 \%)$, and degenerative cells (D) in which the nuclear DNA content does not reach the machine-positive absorbance are $77(0.6 \%)$. On the other hand, cells at machine positive levels (S) were $216(1.9 \%)$ in the five scanning areas. Moreover, the number of cells which were read as two or more aggregating cells (A) was $1229(10.8 \%)$. Following a microscopic observation with an additional Papanicolaou stainning, it was possible to identify directly the morphological features of these abnormal cells in each of scanning areas.

Further preliminary tests were conducted in the following: 105 cases of benign lesions confirmed by final diagnoses were examined. They consisted of 43 cases of normal, 62 cases of mild dysplasia and metaplasia. Malignant lesions observed in 72 cases consisted of 6 cases of severe dysplasia, 44 cases of carcinoma in situ, 7 cases of micro-invasive carcinoma, and 15 cases of frankly invasive carcinoma. The number of malignant cases which was missed was extremely minimal. Here, we investigated the relationship between the number of machine-selected cells and the total cell counts in each of scanning area. It was shown that malignant cells seemed to be contained over $0.7 \%$ of the total cell counts. Based on these criteria, the results here obtained are shown in Tables I and II.

Table I. Results of preliminary test of 105 benign cases on automated cytology

\begin{tabular}{|c|c|c|c|c|c|c|}
\hline \multirow{2}{*}{$\begin{array}{l}\text { Histologic } \\
\text { cytologic } \\
\text { diagnosis }\end{array}$} & \multirow{2}{*}{$\begin{array}{l}\text { No. of } \\
\text { cases }\end{array}$} & \multicolumn{2}{|c|}{$\begin{array}{c}\text { Machine negative } \\
\text { benign }\end{array}$} & \multicolumn{2}{|c|}{ False positive } & \multirow{2}{*}{$\begin{array}{c}\text { Unsatis- } \\
\text { factory } \\
\text { reject }\end{array}$} \\
\hline & & No. & $\%$ & No. & $\%$ & \\
\hline Normal epithelium & 43 & 34 & 79.1 & 9 & 20.9 & 0 \\
\hline $\begin{array}{l}\text { Reserve cellhyper- } \\
\text { plasia metaplasia } \\
\text { mild dysplasia }\end{array}$ & 62 & 47 & 75.8 & 15 & 24.2 & 0 \\
\hline Total no. & 105 & 81 & 77.1 & 24 & 22.9 & 0 \\
\hline
\end{tabular}

Eighty-one cases out of 105 cases of benign lesions, and 69 cases of 72 cases of malignant lesions were positive. There were four false negative cases $(4.2 \%)$ and 24 false positive cases $(22.9 \%)$ in them. The re-evaluation revealed that 2 cases of carcinoma in situ and 1 case of micro-invasive carcinoma were $0.6 \%, 0.5 \%$ and $0.1 \%$, respectively, in the ratio of machine-positive cells. Especially, cases showing 
Table II. Results of preliminary test of 72 malignant cases on automated cytology

\begin{tabular}{|c|c|c|c|c|c|c|}
\hline \multirow{2}{*}{$\begin{array}{l}\text { Histologic } \\
\text { diagnosis }\end{array}$} & \multirow{2}{*}{$\begin{array}{l}\text { No. of } \\
\text { cases }\end{array}$} & \multicolumn{2}{|c|}{$\begin{array}{l}\text { Machine positive } \\
\text { malignancy }\end{array}$} & \multicolumn{2}{|c|}{ False negative } & \multirow{2}{*}{$\begin{array}{c}\begin{array}{c}\text { Unsatis } \\
\text { factory } \\
\text { reject }\end{array} \\
\text { No. }\end{array}$} \\
\hline & & No. & $\%$ & No. & $\%$ & \\
\hline Severe dysplasia & 6 & 6 & 100.0 & 0 & & 1 \\
\hline Carcinoma in situ & 44 & 42 & 95.5 & 2 & 4.5 & 2 \\
\hline $\begin{array}{l}\text { Micro-invasive } \\
\text { carcinoma }\end{array}$ & 7 & 6 & 85.7 & 1 & 14.3 & 0 \\
\hline $\begin{array}{l}\text { Frankly invasive } \\
\text { carcinoma }\end{array}$ & 15 & 15 & 100.0 & 0 & & 1 \\
\hline Total no. & 72 & 69 & 95.8 & 3 & 4.2 & 4 \\
\hline
\end{tabular}

a remarkable inflammatory reaction showed some false images due to the aggregation of leucocytes. It was apparent that the 24 false positive cases seemed to be a result of small clusters of leucocytes.

Further, there were three cases regarded as unsatisfactory specimens, one case of severe dysplasia and 2 cases of carcinoma in situ, which showed the lack of malignant cells in the scanning area, due probably to a sampling error.

Summary. The population screening has been recognized as an efficient means of diagnostic cytology in early carcinomas of the cervix. A microspectrophotometry apparatus was designed based on our original method with bundled glass fibers for scanning of malignant cells. Evidence presented is as follows: 150 cases out of 177 cases of female subjects are positive $(84.7 \%), 3$ of 72 cases $(4.2 \%)$ are false negative, and 24 of 165 cases $(22.9 \%)$ are false positive in automated screening rate.

Acknowledgements. We are grateful to Emeritus Professor Dr. S. Makino, M. J. A., for his revision of the manuscript. The study was supported by grants from the Ministry of Education (no. 987076) and the Ministry of Health and Welfare of Japan.

\section{References}

Melamed, M. R.: Cancer Res., 37, 2801-2812 (1977).

Herman, C. J., and Bunnug, B.: J. Histochem. Cytochem., 24(1), 2-5 (1976).

Nishiya, I., Kikuchi, T., and Moriya, S.: Japan. Acta Obstet. Gynec., 26(12), 1365-1366 (1974).

Nishiya, I., Kikuchi, T., Moriya, S., Shimotomai, K., and Sawamura, I.: Acta Cytol., 21 (2), 271-275 (1977).

Sawamura, I. et al.: Television Soc. Rep., ITA 32-6, 21-24 (1978).

Shibatani, A., and Naora, H.: Experimentia (Basel), 8, 263-264 (1972). 